\title{
The case for and against export mandates for oilseeds and pulses
}

\author{
Dennis O. Ochieng and Bob Baulch
}

An export mandate means that exports can only be made through a structured market, such as a commodity exchange or a formal trading floor/platform where agricultural value chain actors (farmers, commodity exchanges, millers, processors, exporters) conduct organized, regulated trade, usually with specific financial arrangements. In Malawi, a singular example is the tobacco export mandate which has existed for over 70 years with a formal and organized market structure through the auction floors. Only a few other African countries also have export mandates, including Ethiopia (coffee and sesame) and Rwanda (coffee and tea). Some West African countries also only permit exports of cotton through their state marketing boards.

The Government of Malawi has prioritized increasing agricultural diversification and exports in its first and, recently released, second National Export Strategies, especially for widely grown crops with export potential such as groundnuts, pigeon peas, soybean or other beans, and sunflower. Building on the positive effects of mandating tobacco exports and the need to catalyze export diversification away from the declining global market for tobacco, an extension of export mandates to these crops may be expected to be beneficial in the following ways:

1. Export mandates can improve Malawi's foreign currency revenue by up to US\$50 million, while allowing for closer monitoring of foreign exchange inflows into the country and enhancing tax revenue collection. Currently, loopholes due to widespread trade informality and under-reporting of traded volumes and/or prices by exporters, results in losses of foreign exchange earnings and corporate tax revenues.

2. Export mandates can increase the reliability of trade statistics. Strengthening formal markets through export mandates should increase the capacity of the Government to monitor and fully account for economic activity in the agricultural sector, helping to reverse the usual underestimation of agricultural Gross Domestic Product. This should expand private sector participation in agricultural value chains, attract capital inflows for agricultural credit schemes, and more generally enhance the attractiveness of agri-food sector for foreign direct investment-thereby potentially creating employment and expanding the economic base.

3. Export mandates may facilitate the development of structured markets such as the commodity exchanges, thereby helping to diversify Malawi's sources of foreign exchange in the face of declining global demand for tobacco.

4. By facilitating development of structured markets such as commodity exchanges (comex) and warehouse receipt systems (WRS), export mandates can facilitate increased storage. This should help to moderate Malawi's high seasonal price variability and reduce trading margins to the benefit of both producers and consumers. Both Malawi's commodity exchanges operate WRS whose increased use should reduce high postharvest losses, as well as promoting greater access to financial services by producers/traders.

5. Export mandates may stimulate fairer competition between foreign and domestic buyers, especially domestic processors, who often experience shortages of quality raw materials. This would have 'trickle-down' effects in terms of competitive pricing and the development of quality standards that should benefit both farmers and traders. 
Development and implementation of export mandates for the selected crops therefore has significant potential advantages for Malawi's export earnings, crop diversification, and development of the agricultural value chains. However, considering the current production and marketing landscape for oilseeds and pulses, export mandates may not achieve their expected outcomes in the short term because of the following implementation issues:

1. Export mandates will be less effective without development of market-based incentives to encourage trade via the two commodity exchanges, both of which are currently highly liquidity-constrained due to low trading volumes. Higher comex transactions should reduce the marginal cost per ton traded, thereby increasing processors and traders' liquidity (and perhaps allowing them to offer more spot payments to often cashstrapped farmers). So, policy support to catalyze a shift from informal to formal (structured) markets is critical.

2. The limited understanding of the operations and benefits of structured markets, in particular the commodity exchanges, continues to stifle the expansion of trade through such platforms. Hence, there is need to build the capacity of value chain actors and their awareness of the structured market opportunities. A robust market information system and greater penetration of mobile phones are key to this endeavor. (Currently only 40 to 45 percent of rural households own mobile phones.)

3. The limited geographic reach of the commodity exchanges, especially in terms of their warehouse networks, will discourage the participation of small farmers in structured markets. In the absence of collective bulking/marketing mechanisms, most small farmers face high transfer costs and high warehousing fees-both of which may increase rather than reduce informal trade. Such risks can be lowered by promoting farmer cooperative and establishing/registering warehouses in more distant areas, thereby reducing transfer costs.

4. Given Malawi's relatively long and porous borders and the well-established nature of the informal crossborder trade, successful implementation of export mandates will require robust and cost-effective trade monitoring and enforcement mechanisms with clear penalties for non-compliance.

5. Most of the commodities selected for export mandates by the Ministry of Trade have informal and fragmented value chains, which expose value chain actors to various marketing risks, especially when exporting. Even though export mandates may help to lower some of these risks, it is important to establish a strategy to reduce other marketing risks, especially those at the lower end of the value chains which most affect farmers and small traders.

To conclude, export mandates offer various advantages but also pose certain risks which need to be carefully balanced before the proposed export mandate regulations are implemented.

Comments on this note are welcome and may be sent directly to ifpri-lilongwe@cgiar.org.

\section{INTERNATIONAL FOOD POLICY RESEARCH INSTITUTE}

A world free of hunger and malnutrition

IFPRI is a CGIAR Research Center

IFPRI Malawi, Area 14 Office, Plot 14/205, Lilongwe, Malawi | Mailing Address: PO Box 31666, Lilongwe 3, Malawi

T +265-1-771-780 | Email: IFPRI-Lilongwe@cgiar.org | http://massp.ifpri.info

The Malawi Strategy Support Program (MaSSP) is managed by the International Food Policy Research Institute (IFPRI) and is made financially possible by the generous support of the American people through the United States Agency for International Development (USAID), the United Kingdom's Foreign, Commonwealth and Development Office (FCDO), and the Government of Flanders. This publication has been prepared as an output of MaSSP and has not been independently peer reviewed. Any opinions expressed here belong to the authors and are not necessarily representative of or endorsed by IFPRI, the US, UK or Flanders 